\title{
Research on the Teaching Method of the Integration of Curriculum Ideology and Professional Courses
}

\author{
Hao Guo ${ }^{1}$ Jun Sun ${ }^{1, ~ *}$ YuShi Zhang ${ }^{2}$ \\ ${ }^{1}$ School of Management, Dalian University of Technology, Liaoning, Dalian1 16034, China \\ ${ }^{2}$ School of Marxism, Liaoning Normal University, Liaoning, Dalian116000, China \\ *Corresponding author. Email: 747376678@QQ.com
}

\begin{abstract}
The teaching of professional courses is the core link in the process of talent training in universities. It integrates ideological and political courses with professional courses, and follows the "Leadership of People" put forward by General Secretary Xi, integrating the cultivation and practice of the core values of socialism into the whole process of teaching .The reform thinking is a comprehensive and systematic education project that can more effectively enhance the ideological and political awareness of students. In the integration of "curricular ideological and political work" in various majors, there are problems in the professional and ideological and political quality of teachers in professional courses. Each type of curriculum is independent, and there is a lack of internal communication mechanisms and platforms. In order to do a good job of "course ideology and politics", it is necessary to improve professional teachers' responsibility and ideological and political quality, improve teaching methods, build a teaching system that combines "course ideology and politics" with professional courses, and build professional and ideological and political theory teachers. The mechanism and platform for Collaborative education mechanism and platform, including "course ideology and politics" into the teaching assessment and evaluation system, multi-directional, multi-level to improve the effect of coeducation peer education.
\end{abstract}

Keywords: curriculum ideology, professional courses, integration, teaching methods

\section{CONNOTATION AND CHARACTERISTICS OF CURRICULUM IDEOLOGY}

"Education is good for the country, and education is good for the country." The foundation of the university is to build up people and firmly grasp the core point of comprehensively improving the comprehensive ability of talents. This means not only to improve the teaching of ideological and political theory courses in universities, but also to invisiblely intervene in other courses to form synergy. [1] All majors in colleges and universities must clarify the goal of talent training, grasp the requirements for talent training, carry out and promote various tasks around the direction of socialist schooling, attach importance to teaching quality and talent training, and be good at developing the potential of each student in teaching. Grasp the connotation and main points of "course ideology and politics" and implement the fundamental task of Lide Shuren.

\subsection{Connotation of Curriculum Ideology}

Connotation of curriculum ideology

To put it simply, "course ideology and politics" refers to the concept of educating people and ideological and political education throughout the entire process of education and teaching under the guidance of Marxist basic positions, viewpoints, and methods. Practical activities, that is, the curriculum carries ideology and politics, which are contained in the curriculum. Specifically, it is reflected in the following aspects: First of all, in addition to ideological and political theory courses, they must fully tap their ideological and political resources and play a role in educating people; At the same time that college students carry out professional course education, they must also carry out the value guidance of ideological and political education. Secondly, teachers are the main force for classroom education of college students. Teachers must implement the requirements of educating people in ideological and political lessons and professional courses. While teaching professional knowledge, they must also educate people in the classroom, and cultivate students to establish correct values, so as to achieve the effect of comprehensive education. [2]

\subsection{Characteristics of Course Ideology}

"Curriculum ideology and politics" is recessive in educating college students and belongs to recessive ideological and political education. 
multidisciplinary education, provides full-scale, multi-

\subsubsection{Permeability and latentity are its main characteristic.}

The so-called permeability refers to "the development of recessive ideological and political education is always embedded in other social practices, and is always organically integrated with the development of other social practices, and penetrates into the entire process of the development of other social practices." [3]In the process of implicit ideological and political education, it is not a way to educate the educated people directly as in the ideological and political theory course, but to educate the educated people in a silent and silent way Relatively concealed, by adopting such a concealed method to educate the educated person in terms of ideology and morals, the educated person can establish correct values and achieve the silent and effective education effect.

\subsubsection{Ideology and academicity are also its main characteristics.}

The so-called ideological nature refers to the implicit ideological and political education must reflect the clear ideological nature and due political position, reflecting the national mainstream ideology of the overall guiding requirements of implicit ideological and political education. The so-called academic nature refers to the recessive ideological and political education which permeates the ideological and political education ideology in the whole process of disciplines and academics, and transforms discipline resources and academic resources into education resources.

\section{NECESSITY AND FEASIBILITY OF THE INTEGRATION OF CURRICULUM IDEOLOGY AND PROFESSIONAL COURSES}

\subsection{Necessity of The Integration of Curriculum Ideology and Professional Courses}

With the proposal of "course ideology and politics", as an innovative education mode, it is an important change proposed to strive to realize the ideological and political education of college students on the basis of reforming educational ideas and improving teaching methods. Initiatives. [4] Traditionally, relying on ideological and political theory courses to provide ecological civilization education to college students has been difficult to adapt to the severe challenges brought by the new era, which urgently requires universities to change the traditional situation of relying on ideological and political theory courses to provide ecological civilization education to college students. This new mode of ideological and political education and teaching, which takes advantage of course, and comprehensive ecological education. Compared with the past, relying solely on ideological and political theory courses to provide college students with humanistic quality education, at present, the "curricular ideology and politics" developed according to the new educational concept can not only effectively adapt to the new situation that college students' ideological and political education faces in the new era And new challenges, and can accurately grasp and scientifically judge the new features and new performances of ideological and political education of college students in the process of transformation and development, and then better meet the country's new tasks and new requirements.

\subsection{Feasibility of Integrating Curriculum Ideological and Professional Courses}

The professional courses in universities run through the entire university stage. The characteristics of long time and large spatial span determine that professional courses have the advantage of good ideological penetration effects. [5] Moreover, the professional skills and basic knowledge imparted by professional courses directly affect students' future employment. Attention, learning interest, and enthusiasm will be higher than in ideological and political theory courses, so teachers of professional courses can be unknowingly accepted by students in ideological and political education in teaching. The form is relatively hidden, and the effect may be more direct than direct Explicit education is much better.

\section{MEASURES TO STRENGTHEN THE INTEGRATION OF CURRICULUM IDEOLOGY AND PROFESSIONAL COURSES}

\subsection{The Construction of Long-term Mechanism of "Course Ideology and Politics" is a Guarantee}

First of all, attention should be paid to the top-level design work. [6]Students' various education tasks need to be carried out under the leadership of the Party Committee. The "curricular ideology and politics" should be deployed globally. All secondary colleges should actively cooperate to form a corresponding organizational structure and promote Course Ideological and Political "development. Secondly, continue to improve the curriculum evaluation system, expand the scope of teaching, focus on humanities and social responsibility, and improve the teaching evaluation system based on the basic starting point of Lideshuren. Finally, by setting up a typical way, we can give full play to the exemplary leading role. 
must intensify reforms, comprehensively consider issues from multiple angles, and truly incorporate the "curricular ideological and political" element into the teaching of professional courses, Thereby increasing the integration of professional courses and ideological and political education in ordinary colleges and universities. and integrate the "ideological and political elements". In professional courses, the integration of the elements of "course ideology and politics" is actually to strengthen the emotional value of students. Through simulation training, students 'correct professional ethics will be cultivated, and students' professional attitudes of discipline and law compliance will be cultivated. Secondly, innovate the method of "course ideology and politics" and pay attention to the guidance of emotional attitudes and values. The teaching of professional courses is inseparable from the penetration of specific cases. Flexible use of case teaching can enhance students' identity. [7]In this teaching link, select representative cases that are likely to resonate with students 'emotions, infiltrate ideological and political elements in the cases, straighten out the ideological and humanistic values demonstrated by the cases, and achieve the fusion of students' spirit and knowledge To help them form the correct three perspectives.

\subsection{The key to Achieving "Course Ideology" Lies In Teachers}

The key factor for the smooth progress and success of the "course ideology and politics" reform in ordinary colleges and universities lies in teachers. Teachers of professional courses themselves need to improve their cognition of ideological and political education, clarify the relationship between ideological and political education and professional courses, fully understand the humanistic spirit and cultural values contained in professional courses, and guide students to establish correct skills while learning professional skills. Values; professional course teachers themselves need to improve their moral ethics and ideological and political education. [8]A professional course teacher 's behaviors and the state of professional ethics will also affect students 'behavior in a subtle way. Only by being in the students' hearts can they be convinced. Teachers of professional courses themselves need to improve their ideological and political ability in the course, explore their own teaching characteristics in teaching practice, continuously accumulate their own teaching experience, learn to reflect on experience, and then improve their ideological and political ability in the course.

\section{CONCLUSION}

"Course ideology" is a relatively complicated project in ordinary colleges and universities, which combines the characteristics of the current new era. Judging from the current development situation, the reform of "course ideology and politics" requires not only the enrichment of theoretical research, but also the scope of practical research. Therefore, at this stage, ordinary colleges and universities

\section{ACKNOWLEDGMENT}

This work has been supported by the national logistics projects of universities, vocational colleges and universities.

\section{REFERENCES}

[1] Miaoyan Wu. The Second Classroom Research on the Educational Reform of "Curriculum Ideology and Politics"[C]. Institute of Management Science and Industrial Engineering. Proceedings of 2019 International Conference on Modern Education and Economic Management (ICMEEM 2019). Institute of Management Science and Industrial Engineering: Computer Science and Electronic Technology International Society, 2019: 277-281.

[2] Ping Ai. A Preliminary Study on the Cooperative Educational Mechanism of "Ideological and Political Course" and "Curriculum Ideology and Politics " in Practical Teaching[C]. Institute of Management Science and Industrial Engineering. Proceedings of 2019 9th International Conference on Social Science and Education Research (SSER 2019). Institute of Management Science and Industrial Engineering: Computer Science and Electronic Technology International Society,2019:195-198.

[3] Ping Ai. Exploration of the Cooperative Educational Model of "Ideological and Political Course" and "Curriculum Ideology and Politics"[C]. Institute of Management Science and Industrial Engineering. Proceedings of 2019 9th International Conference on Social Science and Education Research (SSER 2019). Institute of Management Science and Industrial Engineering: Computer Science and Electronic Technology International Society,2019:892-895.

[4] He Mu. Construction and Perfection of Integration of Ideological and Political Education in All Courses Based on Synergy Theory[C]. Institute of Management Science and Industrial Engineering. Proceedings of 2019 9th International Conference on Social Science and Education Research (SSER 2019). Institute of Management Science and Industrial Engineering: Computer Science and Electronic Technology International Society,2019:1435-1440. 
[5] Yanhong Du. Exploration of Trinity "Course Ideology and Politics" Teaching in Electrical Specialty[C]. Singapore Management University, Xi'an Jiaotong University. Proceedings of 2019 3rd International Conference on Education, Management Science and Economics (ICEMSE 2019). Singapore Management University, Xi'an Jiaotong University: Jinan Guanping Conference Service Co., Ltd.,2019:531534.

[6] Xin Song. The Teaching Mode Exploration of the Innovative Practice for Agriculture Machinery Specialty from the Perspective of Ideological and Political Education in Professional Courses[C]. Xiamen University Tan Kah Kee College, Hainan University, Sanya University. Proceedings of the 5th International Conference on Social Science and Higher Education (ICSSHE-19). Xiamen University Tan Kah Kee College, Hainan University, Sanya University: Jinan Guanping Conference Service Co., Ltd.,2019:315-318.

[7] San-chi SHE. On the Construction of "Curriculum Ideological and Political" in Colleges and Universities[C]. Xiamen University Tan Kah Kee College, Hainan University, Sanya University. Proceedings of the 5th International Conference on Social Science and Higher Education (ICSSHE-19). Xiamen University Tan Kah Kee College, Hainan University, Sanya University: Jinan Guanping Conference Service Co., Ltd.,2019:327-330.

[8] Jingjing Ye. Enhancement of Ideological and Political Education in Professional Courses by Using Heritage Brands_- Taking the Course "Omnimedia Marketing" as an Example[C]. INTI International University \&amp; Colleges, Tunku Abdul Rahman University. Proceedings of 2nd International Seminar on Education Research and Social Science (ISERSS 2019) (Advances in Social Science, Education and Humanities Research, VOL.322).INTI International University \&amp; Colleges, Tunku Abdul Rahman University: Jinan Guanping Conference Service Co., Ltd.,2019:345348. 